\title{
Paradiplomacy Policies and Regional Autonomy in Indonesia and Korea
}

\author{
Takdir Ali Mukti \\ Department of International Relations, Universitas Muhammadiyah Yogyakarta, Indonesia \\ takdiralimukti@umy.ac.id

\section{Laode Muhammad Fathun} \\ Department of International Relations, Universitas Pembangunan Nasional Veteran Jakarta, Indonesia \\ Ali Muhammad \\ Department of International Relations, Universitas Muhammadiyah Yogyakarta, Indonesia

\section{Stivani Ismawira Sinambela} \\ Department of International Relations, Universitas Potensi Utama, Medan, Indonesia

\section{Sugeng Riyanto} \\ Department of International Relations, Universitas Muhammadiyah Yogyakarta, Indonesia \\ Submitted: 1 June 2020; Revised: 27 October 2020; Accepted: 21 December 2020
}

\begin{abstract}
Abstrak
Analisis ini berfokus pada kebijakan paradiplomatik di Indonesia dan Korea. Kedua negara memiliki kesamaan karakteristik yaitu sebagai negara kesatuan, dan diberlakukannya otonomi daerah pada era yang sama, 1998-an. Penelitian kualitatif ini bertujuan untuk mengkaji tipe paradiplomatik di kedua negara dan mengapa kebijakan tersebut dirasionalkan. Temuan tersebut mengungkapkan bahwa meskipun kedua negara adalah negara kesatuan, aktivisme paradiplomatik berjalan dalam berbagai jenis. Provinsi dan kota di Indonesia menghadapi banyak batasan dan batasan oleh peraturan nasional, sementara pemerintah daerah di Korea memiliki lebih banyak keleluasaan dan kewenangan untuk mempraktikkan paradiplomasi di seluruh dunia. Temuan penelitian juga menggambarkan beberapa provinsi di Indonesia menggunakan paradiplomasi sebagai instrumen untuk memberikan pengakuan internasional terkait penentuan nasib sendiri, dan fakta serupa ini tidak ditemui di Korea. Makalah ini berpendapat bahwa perbedaan jenis kebijakan paradiplomatik di kedua negara dipengaruhi oleh kondisi politik dalam negeri dan biasanya dipengaruhi oleh ada atau tidak adanya gerakan regional.

Kata Kunci: autonomi, gerakan, paradiplomasi, kebijakan, regional.
\end{abstract}

\begin{abstract}
This analysis focuses on the paradiplomatic policies in Indonesia and Korea. The two countries have similar characteristics, namely as unitary state systems, and enacted regional autonomy in the same era, 1998s. This qualitative research aims to examine paradiplomatic types in both countries and why the policies are rationalized. The findings revealed that although both countries are unitary states, paradiplomatic activism runs in different types. Provinces and cities in Indonesia face many restrictions and limitations by national regulations, while regional governments in Korea have more discretions and authorities to practice paradiplomacy around the world. The research finding also portrayed several provinces in Indonesia instrumentalizing paradiplomacy as instruments to provide international recognitions related to self-determination, and this similar fact is not met in Korea. This paper argues that the different types of paradiplomatic policies in both countries are influenced by domestic political conditions and typically influenced by the presence or absence of regional movements.
\end{abstract}

Keywords: autonomy, movements, paradiplomacy, policy, regional.

\section{INTRODUCTION}

Paradiplomacy or foreign cooperation conducted by local governments, such as provincial, regency, or city government, is a relatively new governance practice phenomenon in Asia, including Indonesia and Korea. Paradiplomacy or parallel-diplomacy refers to the behavior and capacity to cooperate with foreign parties by a 'sub-state' entity or regional government for their specific interests (Aldecoa \& Keating, 1999). Paradiplomacy describes the global involvement of a city, federated-state or provincial government in a diplomatic affair equivalent to the state (Leffel, 2018). When state-to-state negotiations often fall into 'gridlocks,' and international 
policymaking also suffers from 'democratic deficits', city-to-city (trans-municipal) networks have received substantial international recognition in recent years as cities can cooperate on a range of global issues with concrete actions. Unfortunately, the role of cities in global governance has been largely neglected by international relations scholars (Chan, 2016).

Paradiplomatic activism is condio sine qua non with the policy regarding regional autonomy. Regional autonomy practices perform various types and experiences around the world. One type of regional autonomy policy can be observed in Indonesia and Korea, developing quickly at the same time, started during the Indonesian Reformation Movement in 1998 and during President Kim Daejung's era in the same year. The type of autonomy shapes the mode of paradiplomacy policy in every country.

President Kim Daejung made the decentralization policy one of his top priorities during his term of office, and this policy was continued by President Roh Moohyun and President Lee Myung-bak (KLRI, 2017). This regional government was divided into the high-level and low-level regions. This local autonomy refers to the political decision-making and administration by the society within a certain region by maintaining relative independence from the central government. Local autonomy mainly consists of autonomy authority upon local affairs and budgeting capacity independently, organization and governance management, trade and promotion, either abroad or domestically (Korea.net, 2019). The local self-governing body, playing a key role in Korea's local autonomy, is the administrative agency that maintains close relationships with its citizens. The local self-governing body is made up of local citizens and is a legal entity. Korea has two forms of self-governing bodies; macro-level bodies like the Special City, Metropolitan City, Special Autonomous Region, Do or Special Autonomous Province, and primary-level bodies like Si, Gun or Gu. Residents may participate mainly through elections in the local autonomy (NGII, 2017). Explicitly, the paradiplomacy term is not mentioned in any Korean Government regulations, but paradiplomatic activism is commonly and largely practiced in regional governments to promote trade, cultures and education in other countries.

Meanwhile, Indonesia's government regulates its decentralization policy through several regulations providing wider authority to the regional government, including the authority to cooperate with foreign parties or paradiplomacy. The main provision of local autonomy in Indonesia is regulated in Law No.23 of 2014 (Mahi, 2016). Specifically, paradiplomatic authority is regulated in the Government Regulation No.28 of 2018 regarding Local Cooperation and The Decree of the Foreign Affairs Minister No.3 of 2019 regarding the Guideline on Foreign Relations by Local Government. With this paradiplomatic authority, regional governments in Indonesia can establish direct cooperation with various foreign parties, with either foreign regional government or foreign private parties.

By looking at the description of regional autonomy in Korea and Indonesia above, the type of regional autonomy is highly similar to the extent of its powers. However, at the practical level, paradiplomacy in Korea shows more flexibility than in Indonesia. According to Wolff (2007), it is related to the share of authority between the central government and the regions related to paradiplomacy matters. For the state to enjoy sovereignty as much as possible and for the people to benefit from it, the state must share the power to other players in the international arena, in paradiplomacy as an example, which clearly shows that the state remains the highest sovereignty holder, yet the regional government has limited authority mostly decided by the central government (Wolff, 2007). In this context of 'sharing' sovereignty, the paradiplomacy policies or politics shall be formulated with utmost care to support the national development. The paradiplomacy politic discussed in this research is the government's official policy in paradiplomacy embodied in regulation-making or paradiplomacy practice that supports the pursuance of the state's objectives.

Other than its positive potential in supporting national development, policy or politics, the inappropriate policy may lead to the opportunity for regional government ventures that may interfere with or threaten the national interest instead. According to Noe Cornago, the regional 
government may establish relations with foreign governments to obtain recognition upon its regional independence or known as 'protodiplomacy' (Cornago, 2018), which is when the autonomous government uses paradiplomacy as the instrument for secessionism movement (Vicuňa, 2015). Therefore, utmost attention in formulating the national paradiplomacy is highly necessary, considering that paradiplomacy may create either cooperative or conflictual relations with the central government. It will depend on the social, economic, and political constructions in the regional government area. A radical nationalist group will make the relations conflictual (Cornago, 2006).

Paradiplomacy is a double-edged sword: it can be either an instrument for development or an instrument for strengthening ethno-nationalism identity to fight for its self-determination rights. Ethno-nationalist groups try to design paradiplomacy as a part of their fight to gain support from abroad. It happened in Aceh and Papua. Paradiplomacy management patterns also have similarities in several countries, influenced by the dynamics of the local political movement in which paradiplomatic activism is often used as the instrument in the secessionism movement. In other words, paradiplomacy management by regions with separatist movements, either in the federal system (such as Catalonia, Spain) or in the unitary state (such as Aceh, Indonesia), is reflected in its regional regulation regarding paradiplomacy affairs (Mukti et al., 2019). It indicates crucial problems in Indonesian paradiplomatic policies about how big the sovereignty 'share' is allocated to the autonomous region in its international relations.

From the explanation above, this article focuses its discussion on paradiplomacy politics (legal policy) in Indonesia and Korea to identify the applied types of paradiplomacy policies and to explore the rational reasons behind the policies. In a qualitative manner, this article used the theoretical approach of regional autonomy and sovereignty sharing as the analysis framework by using several indicators on each type of paradiplomacy policy. This article argues that, although Korea and Indonesia have the same government system as unitary states and practice a very similar regional autonomy, there are striking differences in their paradiplomacy practices due to differences in potential threats that arise from political dynamics in the regions.

\section{LITERATURE REVIEW}

The central government granted regional autonomy in Indonesia after the Soeharto Regime collapsed, which had been in power for 32 years. This regime was so centralized that local governments only functioned as 'implementing agencies' of national development programs (Nasution, 2016). The basic concept of regional autonomy applied relied on granting all government authority to regions outside the six fields of the central government's authority: defense-military affairs, foreign policy, monetary-fiscal, judicial, religious and national planning. In its development, the authority of the regional government underwent revisions until 2014 when the issuance of law on regional government, which by observers was considered as a limitation of regional authority when compared with previous laws from 1999 and 2004 (LPS Initiative, 2015). Nevertheless, regional authority related to paradiplomacy matters is still given space in the new regulation, and even its implementation is strengthened by the Presidential Regulation 2018, as mentioned earlier.

Meanwhile, the Korean Government designed its regional autonomy policy carefully during the 30-year preparation period, and it began to be implemented massively in the 2000s, making the regional autonomy in this country more organized (NGII, 2017). The functions of decentralizing government to regional governments involve a broad and authoritative field. In addition to the main functions carried out by the central government, as is generally the case in a unitary state system of government, matters relating to territorial, organizational, managerial jurisdiction in local government, promotion of general welfare, health, and promotion of industry, trade, agriculture, education, and all investment are left to the regions, although there is criticism of a tendency for the central government to strengthen its authority (Choi et al., 2012). Paradiplomacy policy becomes part of the authority of the promotion of industry, trade, investment, agriculture, education, tourism and other matters abroad that requires cooperation with regional governments from 
abroad, mostly driven by Local Government Development Institutes (LOGODI) attached to the institution of Korean Ministry of Security and Public Administration. LOGODI offers many collaborative programs with foreign sub-national parties or regional governments from abroad in the areas of financial assistance, local administration, and development in general (Tavares, 2016).

By granting the authority to carry out paradiplomacy to regional governments as happened in Korea and Indonesia, and generally the practice of paradiplomacy in European countries, the emergence of 'sub-state actors' or regional governments complements Joseph Nye's(1971) of transnational relations patterns ( $\mathrm{Nye}, 1971)$. If 'sub-state actors' or 'Local Government (LG)' are included in the transnational relation patterns proposed by Nye and Keohane, which consists of Government (G), Society (S), and Inter-Governmental Organization (IGO), and then combined with the International Non-Governmental Organization (INGO), the pattern of international relations by autonomous regions can be described as follows (Mukti, 2012):

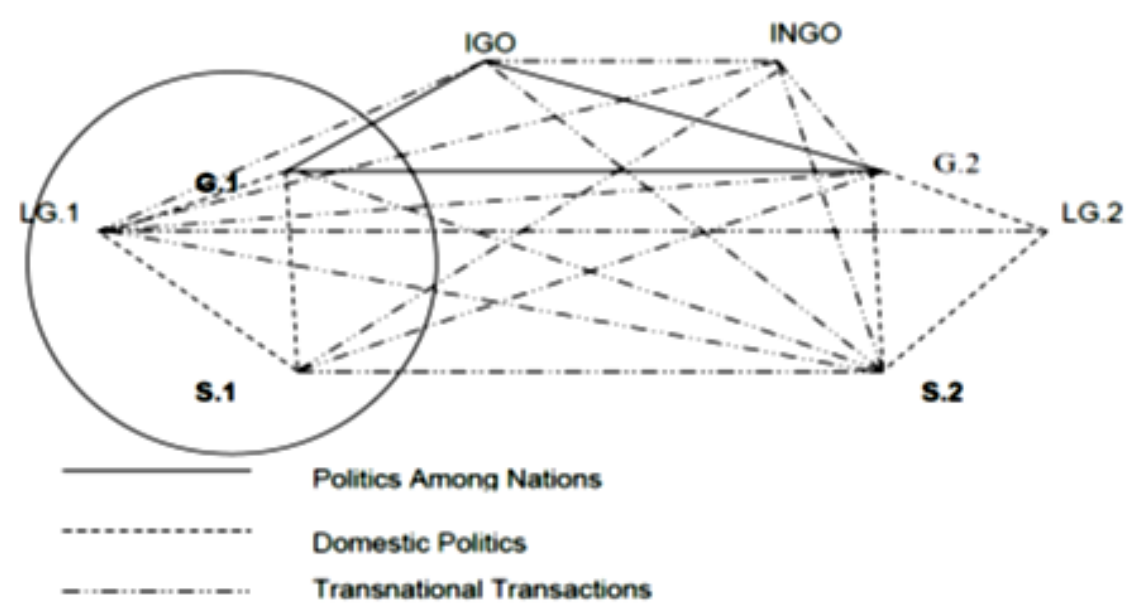

Figure 1. The existence of Local Government (Sub-state Actors) as actors of relations between nations (Nye,1971; Mukti,2012)

Figure 1 illustrates that the local government or autonomous region is the meeting point of two types of lines. First, the type of line that shows the interaction of all domestic affairs with the central government and domestic society meets the second line, which describes the interaction in all foreign affairs with foreign parties. The autonomous region is in the intersection or 'line meeting' between affairs with foreign parties or foreign affairs and affairs with the central government or domestic affairs. Therefore, the importance of autonomous regions in the study of international relations cannot be ruled out at all, given that, relatively, autonomous regions can carry out international relations directly with foreign parties, both intergovernmental and in cooperation with foreign non-governmental actors, in which the non-government actors can freely bypass relations without involving the central government. These actors can be in community groups and tribes (societies), economic interest groups, multinational companies, and even parts of a country's government bureaucracy. These parts of the government bureaucracy sometimes act by interacting directly with foreign parties without the knowledge of the central government (Mukti, 2013).

Wolff (2007) stated that the central government must be willing to share its sovereignty with the regional government, and how much of the 'share' of sovereignty will undoubtedly vary in each country. In the context of the 'share' of sovereignty between the central government and regional governments, a study conducted by Noe Cornago (2000) on paradiplomacy in Asia-Pacific revealed interesting facts from paradiplomacy carried out by several provinces in China. Xinjiang Province, China, in the 
1990s, sought to establish cooperation with neighboring provinces in the west, the territory of Pakistan. Their motivation to establish this relation was driven more by the religious similarity between the majority of the Xinjiang people and the people in Pakistan. The Beijing Government strongly opposed this effort. However, Xinjiang Province did not want to cancel its collaborative efforts, so as a reaction to the stubbornness of Xinjiang Province, the Beijing Government forcibly closed the highway in the Karakorum in 1993-1997, which was the pulse of Xinjiang people's transportation. The Xinjiang case is an example of how the central government can be very 'possessive' of its sovereignty if the paradiplomacy is driven by political interests and not economic or cultural. However, the opposite is also true in southern China, where the Beijing Government is promoting closer relations between Yunnan Province and provinces in the Northern part of Burma, and Guangxi Province with provinces in northern Vietnam.

On the other hand, Cornago also explained the practice of paradiplomacy in the provinces of Jilin and Nei Mongol in North Korea, which took part in the Tumer River Cooperation collaboration initiated by the United Nations Development Program (UNDP). Because of its nature initiated by an outside party, UNDP, the collaboration with the regional government of North Korea was very undeveloped (Cornago, 2000). Furthermore, faced with profound domestic developments and a dynamic external climate, Yunnan was inspired to participate in cross-border cooperation and consolidate its external relations forces. It was followed by a discussion on how external affairs forces allowed Yunnan to exploit three specific resources to persuade neighboring countries to cooperate with it: the growth of infrastructure, economic statecraft and diplomatic efforts. Additionally, it was argued that Yunnan's increased external powers had propelled its position as an agent in international relations toward recognition by neighboring countries and the Chinese central government (Song, 2019).

The case of Yunnan and Guangxi Provinces is proof that the central government can support regional governments to carry out paradiplomacy if it follows the central agenda. In fact, Guangxi has played a crucial role in laying out the BRI groundwork and substantiating initiative policy formulation. It has served as the key policy implementer of Beijing. At the same time, it must take note of the function of local governments, as in Guangxi's case, can be more than a passive reactor to central government policy initiatives ( $\mathrm{Li}, 2019)$.

The Chinese Government seems to use diplomacy to establish more massive economic relations with other countries, especially to expand its export markets and cultural relations. Therefore, there has been agreements cooperation in a fantastic amount between the provinces in China with the states in Canada, Australia, the United States, and hundreds of paradiplomacy cooperation formed. It is where the Chinese Government shows its high pragmatic flexibility in establishing international cooperation with various nations in the world, regardless of their ideological background.

This Cornago's study opens a new atmosphere since paradiplomacy has not been extensively explored in unitary, centralized states. Some scholars, such as Hocking (1986), have even called for sparing judgment as to whether paradiplomatic activities exist in a country by a cursory look at its constitution alone; instead, they have stressed the importance of observing the extra-constitutional actions of the subnational governments of a country under examination. The attention paid to unitary systems has been sparse compared with the literature examining paradiplomacy in federal states (Hocking, 1986). As Elazar (1997) and Kincaid (1990) mentioned in Liu \& Song (2020), this neglect has resulted from the long-held view among paradiplomatic researchers that paradiplomacy is more observable in Western federations or federal-like nations (Liu \& Song, 2020).

Meanwhile, in Europe, the practice of paradiplomacy has been going on for quite a long time, which is part of the continuing history of integration in each country. According to Lecours, the practice of paradiplomacy that they do can be categorized into three groups: First, the relations and cooperation of regional governments or 'sub-states' oriented only for economic purposes such as market expansion, investment development abroad, and mutual investment. This relation involves complex motives, such as politics or culture. The United States and 
Australia commonly practice this type of transnational interaction. Second, paradiplomacy involves various fields in collaboration or 'multi-purposes', between economics, culture, education, health, and technology transfer. The concept of this relation refers to a decentralized cooperation model of foreign cooperation. Several provinces in Germany, or 'lander', practice this model relation and the Rhone-Alpes regional government, France, has relations with several African states such as Mali, Senegal, and Tunisia, as well as provinces in Vietnam and Poland. The third category is complex paradiplomacy involving political motives and specific regional nationalist identities. They try to establish international relations with great zeal to express the specific and autonomous national identity of their region, which is different from most regions in their countries. Those practicing this model include Flanders-Belgium,
Catalonia-Spain, Quebec-Canada and the Basque Country (Lecours, 2008). Kuznetsov's study (2015) unveiled that paradiplomacy policy was generally more relaxed in federal states, but the practice of paradiplomacy in unitary states showed that regional governments also carried out extensive international relations activities (Kuznetsov, 2015)

From the various policies/politics of paradiplomacy practiced in international forums, the author grouped them into three types of political paradiplomacy: isolative, conservative, and progressive. In each type, some indicators can be used to identify a country's policies/politics, as shown in the table below. By referring to this typological paradiplomacy table, an analysis of the policies/politics of the government of the Republic of Indonesia and Korea was carried out.

Table 1. Typology of Paradiplomacy Policye Effectiveness

\begin{tabular}{llll}
\hline Indicator & \multicolumn{1}{c}{ Tsolative } & \multicolumn{1}{c}{ Conservative } & \multicolumn{1}{c}{ Progressive } \\
\hline Foreign Policy & $\begin{array}{l}\text { Present at the central } \\
\text { level }\end{array}$ & $\begin{array}{l}\text { Present at the central } \\
\text { level }\end{array}$ & $\begin{array}{l}\text { Present at the central } \\
\text { level }\end{array}$ \\
\hline $\begin{array}{llll}\text { Diplomatic Role } \\
\text { for foreign cooperation } \\
\text { initiatives, but there are } \\
\text { assignments from the } \\
\text { center }\end{array}$ & $\begin{array}{l}\text { There is an authority } \\
\text { initiatives, but it is fully } \\
\text { controlled by the center }\end{array}$ & $\begin{array}{l}\text { There is an authority } \\
\text { on cooperation } \\
\text { initiative, and some } \\
\text { diplomacy activities can } \\
\text { be carried out by } \\
\text { regional governments } \\
\text { (paradiplomacy) }\end{array}$ \\
\hline $\begin{array}{l}\text { Representative Offices } \\
\text { Abroad }\end{array}$ & $\begin{array}{l}\text { There is only a } \\
\text { representative office } \\
\text { from the central } \\
\text { government }\end{array}$ & $\begin{array}{l}\text { There is only a } \\
\text { representative office } \\
\text { from the central } \\
\text { government }\end{array}$ & $\begin{array}{l}\text { Local governments with } \\
\text { certain criteria can } \\
\text { open representatives } \\
\text { abroad (person/office) }\end{array}$ \\
$\begin{array}{l}\text { Making Cooperation } \\
\begin{array}{l}\text { Documents with } \\
\text { Foreign Parties }\end{array}\end{array}$ & $\begin{array}{l}\text { Wrom the center (full } \\
\text { power) }\end{array}$ & $\begin{array}{l}\text { With Mandate Letter } \\
\text { from the center (full } \\
\text { power) }\end{array}$ & $\begin{array}{l}\text { It does not require a } \\
\text { Mandate Letter, but } \\
\text { coordination with the } \\
\text { center }\end{array}$ \\
\hline
\end{tabular}

Note. Adapted from Criekemans (2006); Cornago (2000, 2010); Kuznetsov (2015);Keohane (1972), Mukti (2013), and Wolff (2007) 


\section{RESEARCH METHOD}

In this qualitative study, data were obtained from field areas in Indonesia and Korea by interviewing informants ranging from leaders in governments to academics. This methodology was purposive in that identification of informants was left solely to the researchers' evaluation of their compliance with the purpose of the analysis.

Selected documents from the relevant sources, both in Indonesian government and Korean administration, local government relations reflected in official site, and in other institutions, were gathered and checked. The data analysis methodology used in this research refers to the technique of an immersive model of analysis, which is an analysis model that rests on three components: data elimination, data interpretation and the drawing and testing of conclusions. The triangulation method was used to verify the quality of the data before it was analysed further.

\section{RESULT AND ANALYSIS TYPOLOGY OF PARADIPLOMACY POLICY IN INDONESIA AND KOREA}

As democratic countries with a unitary state system, Indonesia and Korea have the same basics in running government wheels. Implementing administrative decentralization policy toward regional governments also has some similarities, but it does contain paradoxes (Heo, 2018). In this decentralization policy package, the authority of paradiplomacy is given by the central government of the two countries to the regional government, analyzed using the indicators mentioned in the table above. Indicators were verified using regulatory clauses in national law that must be obeyed in the practice of paradiplomacy for regional governments.

\section{Foreign Policy and Paradiplomacy}

Paradiplomacy carried out by the regional government in Indonesia is mandatory within the framework of the system of the Unitary State of the Republic of Indonesia and must follow foreign policy objectives. Indonesia's foreign policy emphasizes solidarity between developing countries, supports the struggle for the independence of nations, rejects colonialism in all forms, and increases national independence and international cooperation for the welfare of the people. This provision applies to all actors in foreign relations, both government and non-government, at the central and regional levels. In national law No. 37/1999, the implementation of foreign cooperation by regional governments must be with regional governments of which the countries have diplomatic relations with Indonesia.

The principle of paradiplomacy is in accordance with Cornago's opinion of 'normal paradiplomacy', which must conform to the central government's foreign policy so that regional government activities will be 'parallel' with 'diplomacy' conducted at the national level (Cornago, 2010). Control over regional diplomatic missions is carried out by the Ministry of Home Affairs and the Ministry of Foreign Affairs in interdepartmental coordination meetings before the cooperation draft proposed by the regions is approved by the central government.

Indonesia's Foreign Ministry stipulates that paradiplomacy must uphold the principle of non-intervention. Several provisions limit paradiplomacy activities by regional governments, including (a) the implementation of foreign cooperation must be with countries that have diplomatic relations with the Indonesian Government; (b) Regional government affairs; (c) abroad regional governments and abroad institutions do not interfere in domestic government affairs; (d) in accordance with national and regional development policies and plans; and (e) equality of the status of the regional government, for example, a province with a province and a city with a city.

Supervision of these regulations is getting increasingly strict on increasing unconventional threats and indirect interventions on regional policies, which can enter through channels of direct relations between nations. This non-traditional security threat has become an alert for all nations in the world (Chng, Cook, \& Ewing, 2013), including Indonesia.

Immigration, people smuggling, illegal workers, business permit issues in the area by foreign parties to terrorism are severe problems for several regions in Indonesia, especially in border areas (Alami, 2016). Of 
course, in general, it influences Indonesian security architecture (Surwandono \& Ramadhani, 2016). Security considerations in the national paradiplomacy policy of a country are a necessity primarily related to human securities issues (Rodrigues \& Mattioli, 2017). In this situation, the Indonesian Government's position to tighten its supervision of regional governments in carrying out their paradiplomacy finds their reasons, although this limitation and supervision of paradiplomacy can be seen as a 'lack of trust' from the central government to the regional government diplomacy mission.

Meanwhile, in its national law on local autonomy, the Korean Government provides flexibility to regional governments in establishing foreign relations with various foreign parties, both foreign governments and foreign privates. The authority of regional government diplomacy is seen as part of regional promotion efforts in encouraging industry, investment, trades, education, and tourism. There are no rigid restrictions on what regional governments should not do. In fact, the Regional Council was given the authority to resolve issues related to exchanges and cooperation with regional governments from abroad (KLRI, 2017). Indeed, the paradiplomacy activities must remain within the scope of the local government's power and not touch the authority of the central government regarding Korean foreign policy.

Regional governments in Korea have the full confidence of the central government to promote their specific regional interests abroad by collaborating with their foreign partners. The practice of paradiplomacy carried out by provinces such as Gyeongsangnam-do, Gyeongsangbuk-do, Gyeongnam-do, Chungcheongbuk-do, and Seoul Metropolitan demonstrates the freedom and capacity of regional governments in establishing their foreign cooperation. Each of these provinces cooperates with more than 20 foreign regional governments around the world in various forms of cooperation and their specific affairs (Korea.net, 2019). The Korean Government also gives regional governments flexibility to join regional governmental organizations in the Asian region, such as the North-East Asia Regional Governments (NEAR), consisting of 29 provinces from six countries, including Korea, North Korea, Mongolia, Russia, Japan, and China.
Korea is the country with the most provinces joining this association (NEAR, 2017).

\section{Diplomatic Role}

The diplomatic role of the Indonesian Government is explicitly determined as the domain of the central government. Regional government activities with the dimensions of relations between countries must carry out consensus and coordination with the center to obtain approval for their cooperation. In national law No. 24 of 2000, it is stated that the Minister of Home Affairs and the Minister of Foreign Affairs coordinate the implementation of foreign relations and the implementation of foreign cooperation, carried out by the regions. On the other hand, as a regional leader, the regional head acts on behalf of his region in signing cooperation agreements with foreign parties. The diplomatic role of the regional government in Indonesia is limited to its authority in making cooperation initiatives with various parties abroad; however, all activities are controlled by the center.

Besides, in the midst of the paradiplomacy practice between different countries, especially between countries that adhere to the federal system and the unitary state system (Lequesne \& Paquin, 2017), the Indonesian Government applies equalization in paradiplomacy relations. The Indonesian Government stipulates in its constitution that regional government cooperation must meet the requirements of equality of government or territorial status, for example, provinces with provinces and cities with other cities abroad. This principle is closely related to security reasons and exploitation of regional resources by foreign parties, including avoiding social hazards that might be caused by unbalanced relations. Between a province in Indonesia and a foreign country, China, for example, can mobilize resources of the Chinese state to enter a province in Indonesia on a massive and structured basis (Henschke, 2019). It is undoubtedly highly dangerous for Indonesia.

In Korea, the center authorizes regional government initiatives on foreign cooperation, and some of its diplomatic activities can be carried out by local governments. The local government designs and implements its economic and trade diplomacy globally 
and allocates hundreds of millions of won in financial support. This paradiplomacy practice can be seen in Gyeongsangbuk-do, which expansively promotes the globalization of its local economy by finding various channels for export in global markets and sending public officials to potential countries to face the challenges of the era of economic competition around the world. The province sends its public officials to Tokyo (1 person), Osaka (1 person), New York (1 person), Los Angles (2 persons), Beijing (2 persons), Chennai, India (1 person), Phnom Penh, Cambodia (1 person) for the purpose of lobbying and export promotion from Gyeongbuk (Government of Gyeongbuk, 2015). Gyeongsangbuk-do expanded its diplomatic activities by signing Memorandums of Understanding (MOU) and Friendly Ties with foreign sub-national and foreign private parties. The province also appoints its local diplomats abroad to support international affairs. Gyeongsangbuk has appointed Honorary Advisory of 95 persons in 47 countries that were fully supported financially and other work facilities (Government of Gyeongbuk, 2016).

The same practice of paradiplomacy has been carried out by other provinces such as Chungcheongnam-do, Chungcheongbuk-do, Seoul Metropolitan, and Gangwon-do. These provinces established paradiplomacy programs with the firm and clear objectives, such as expanding infrastructure for the globalization of provincial governments, enhancing global mindsets in rural areas through multicultural experiences, promoting provincial policies internationally and contributing to rural development in less developed countries (Government of Gangwon, 2018), and forming a global marketing system as carried out by Chungcheongbuk-do to bring out promotions throughout the world digitally (CBGMS, 2018). Seoul Metropolitan independently developed the City Diplomacy program with its primary mission to solve global urban issues, to contribute to the peace and development of Northeast Asia, city diplomacy based on public-private diplomacy, and establishing foundations for city diplomacy. A complex international design has cooperated with 79 major cities around the world and joined 14 international organizations (Government of Seoul, 2019).
The description of paradiplomacy activities by regional governments in Korea shows that the authority of foreign cooperation initiatives owned by local governments is utilized optimally for the promotion of regions abroad without any violation of diplomatic authority politically owned by the central government.

\section{Opening of Abroad Representative Offices}

The Indonesian Government does not allow regional governments to open trade or diplomatic offices abroad in response to the opening of regional government representatives since the 1990s, for example, in Western Australia, Johor and Penang, Malaysia, and Singapore. It is feared that the opening will be a door for other regions with particular vulnerabilities to do the same thing abroad. Government Regulation (PP) No. 28 of 2018 confirms in Article 27, paragraph (1) that the implementation of cooperation must meet the requirements of point (c), that is, the regional government does not open a representative office abroad (GOI, 2019).

In this context, overall security considerations take precedence. The secure principle of political, juridical, and security becomes a severe discussion when an interdepartmental coordination meeting is held in discussing cooperation plans proposed by the regions. The regional government must be able to convince the center about the four aspects of cooperation security. Regional governments in submitting cooperation plans with foreign parties must follow their respective fields of authority: economic, socio-cultural, and other technical cooperation. It is stated that the field of foreign cooperation covers: (a) the field of economic cooperation, which includes trade, investment, employment, maritime affairs, fisheries, science and technology, agriculture, forestry, mining, population, tourism, environment, and transportation; (b) the field of socio-cultural cooperation, such as education, health, youth, womanhood, sports and arts, as well as other fields of cooperation. Areas outside these affairs will tend to be perceived as insecure cooperation from various aspects.

In the matter of opening representative offices of foreign governments abroad, the Korean Government made concessions by appointing Korean citizens abroad 
to become 'honorary advisors' who acted as local diplomats residing in foreign local governments to carry out lobbying functions and promotion of the interests of local government abroad (Government of Gyeongbuk, 2016). One honorary council from Gyeongsangbuk Province has been placed in the Daerah Istimewa Yogyakarta Province, Indonesia, collaborating since 2005 (Mukti, 2013). Honorary advisors are functional and not in the form of official representatives, individuals who can create business networks and lobby at the level of government and business abroad.

\section{Making Cooperation Documents with Foreign Parties}

The Indonesian Constitution states that the logical consequence of the Republic of Indonesia as a joint state system is that regional government is an integral part of the national government. Therefore, policies made and implemented by the regions are an integral part of national policies or national plans. In this perspective, all planned cooperation agreements made by regional governments in Indonesia must obtain approval from the center before signing the process. Local governments cannot act on their behalf, but they must act on behalf of the central government by granting a 'full power letter' to the regional head. The full power, interpreted as a mandate given by the central government through the Minister of Foreign Affairs, to carry out a part of the central government's authority is handed over to the regions in foreign cooperation following the principles of assigning affairs to the autonomous regions. Along with this power of attorney, emphasizing that if there is a dispute or conflict in an international agreement signed by the regional government, then the central government will automatically be involved directly through its diplomatic apparatus to deal with the problem. Here, the Ministry of Foreign Affairs acts as the only door for all matters with foreign parties, or as 'one gate policy', which must be passed in making international agreements, even if it is conducted by local governments (LPS Initiative, 2015).

A power of attorney or 'full power' from the central government can only be issued if the foreign cooperation draft proposed by the region has been approved by the local lawmakers (local parliament), the Ministry of Home Affairs and the Ministry of Foreign Affairs. The oversight of the local parliament (DPRD) on the implementation of international cooperation in the regions becomes crucial because it relates to the use of local government budgets that must be approved by the local parliament.

On the other hand, the Korean Government policy gives local governments authority to design, negotiate, and make agreements with their respective paradiplomacy activities. Thus, regional governments in Korea do not need a 'full power letter' to sign their foreign cooperation. In fact, in article number 39 in the Local Autonomy Act, Korea, it is stated that the local council is obliged to resolve any problems that deal with foreign cooperation created by the region. Here, the principle of decentralization of paradiplomacy authority is evident in regional government autonomy (KLRI, 2018).

As a case in point, signing collaboration between the Gyeongsangbuk Province and the Daerah Istimewa Yogyakarta Province in 2005, the Gyeongsangbuk Provincial Government did not bring a full power letter from the Korean Central Government, even though Jakarta had given the Governor of Yogyakarta full power. This difference does not interfere with the validity and the implementation of productive cooperation between the two provinces in investment and education.

In the manners of the explanation above, it can be categorized that the types of Indonesian and Korean paradiplomacy policies belong to different groups. Korea gives regional governments more authority to participate in regional diplomacy and with full confidence in the regions to carry it out. Planning, final responsibility, and resolution of the problems that may arise from paradiplomacy activities are in the administrative area of regional governments. Meanwhile, the Indonesian Government provides paradiplomacy authority to the local government, accompanied by restrictions that bind their paradiplomacy activities. The center does not fully trust the regions to freely establish foreign cooperation and remain under the central government's control. Planning and final responsibility of paradiplomacy activities are in the central government's hands, including resolving problems from paradiplomacy activities not in the hands of local governments. 


\section{PARADIPLOMACY POLICY AND ISSUE ON SECESSIONISTS MOVEMENTS IN INDONESIA}

The unique fact in this research shows that the issue of paradiplomacy and regional autonomy in Indonesia is overshadowed by the threat of secessionists to carry out political movements to gain independence in their territories. This domestic threat condition is not found in the decentralization process in Korea. West Papua and Aceh are two provinces in which secessionists heavily control local politics. The Aceh conflict was formally resolved by the Helsinki Memorandum of Understanding (MOU) in Finland in 2005 between the Republic of Indonesia and the Free Aceh Movement (Gerakan Aceh Merdeka or GAM). However, the issue of extending the authority of paradiplomacy, proposed by former GAM activists who had become local political elites both in the executive and local councils, was vehemently opposed by Jakarta. Political elites in the Aceh Government endorsed the 2013 local regulation that attached paradiplomacy power to Aceh's supreme leader, Wali Nanggroe (The Guardian of Aceh), to play the role of broad international relations authority. The Center sees it as an effort to seek Aceh's legitimacy and recognition internationally (Mukti et al., 2019). It contrasts with national law, which places the authority of the paradiplomacy on the regional chief executive or governor. Responding to the dynamics of local politics in Aceh since 2009, the President issued a particular decision to regulate paradiplomacy affairs for Aceh, which stressed that only the governor could sign and carry out foreign cooperation. The presidential decree also requires Aceh to include phrases saying that Aceh is part of the Republic of Indonesia in each of its international cooperation documents (Mukti, 2019). This specific policy on Aceh's paradiplomacy clearly illustrates the potential for the exercise of paradiplomacy authority that does not follow the central government's foreign policy.

Meanwhile, in West Papua, the Papuan Liberation Front politically influences the local political elites in running the government in this region. Local politicians will be at risk of not being elected if it goes against the large flow of Papuan people who want self-government.
Benny Wenda's United Liberation Movement for West Papua (ULMWP) has successfully collected 1.8 million Papuan signatures for a petition to support a free referendum from Indonesia (CNN Indonesia, 2019). Although the Indonesian Government contested the validity of this document, support for advocacy on human rights violations and references in Papua continues to flow from the international community, among others, Papuan independence support from seven pacific countries (FWPC, 2016), and support for solving human rights issues in Papua has reached 79 countries in Africa and Melanesia (ACPG, 2019).

In the eyes of the Papuans, the transfer of government from the Netherlands to the Republic of Indonesia through the New York Agreement of 1962 and the implementation of the Act of Free Choice in 1969 was not fair, although overseen by the United Nations, the act is still regarded as Indonesia's military occupation of Papua (Singh, 2019). In fact, the British Government Minister for Asian and Pacific Affairs, Mark Field, considered the Act of Free Choice a 'truly flawed process', but said there was no international desire to review the Indonesian Government's legitimacy in Papua (Doherty, 2019).

The ULMWP resistance group is building its military wing and has officially declared war on the Republic of Indonesia in January 2019 from Port Moresby, Papua Nue Guinea (Saputra, 2019). This ULMWP declaration of war was supported by the people of PNG and governors in the Port Moresby and Oro Provinces, who attended the declaration and demonstrated with thousands of people supporting Papuan independence (RNZ, 2019). On the other hand, the paradiplomacy relation between Port Moresby and Oro Province with Papua Province is very close. This relation can be seen from the act of visiting each other and the presence of the Governor of Papua, Lukas Enembe, at the PNG Independence celebration at the invitation of the Governor of Port Moresby, Powes Parkop (Papua Today, 2018).

From the perspective of paradiplomacy, the fact that the Papua Governor's relations with the governor in the PNG region that all fully supported the referendum for Papua could lead to Jakarta's distrust of local political 
elites regarding their loyalty to Indonesia's national integration of Papua. The Governor of Papua's verbal statement indeed stated that Papua was part of Indonesia; however, his friendship with the Indonesian Government's political opponents could be interpreted as political ambiguity.

Another fact is, the gathering of ULMWP fighters and the ministers of the Free Papua State in the PNG region, relatively free in its activities in neighboring Papua, including being a place of the declaration of war on the Republic of Indonesia, indicates the great real political support of the PNG political elite for the struggle Papuan independence. It is understandable because Governor Powes Parkop of Port Moresby's capital city is a chairman of the Social Democratic Party. Meanwhile, the source of political support for the Governor of Papua, Lucas Enembe, is the mass base of the Papuan people who strongly support the ULMWP political movement. This highly dependent relation makes the Indonesian Government behave rationally to limit the authority of its paradiplomacy toward regional governments to avoid what Cornago (2018) refers to as protodiplomacy or local diplomacy seeking to gain international recognition for the struggle for ethno-nationalism to achieve self-determination (Cornago, 2018). Understandably, the Indonesian Government will keep this protodiplomacy from happening to not interfere with its integrity internationally.

The Indonesian Government, in maintaining its sovereignty abroad and minimizing the risks using paradiplomacy as an instrument of struggle for secessionists in gaining international recognition, tends to withhold or limit the authority of regional government paradiplomacy. The authority of broad paradiplomacy, if it is in the hands of local elites who support secessionism, has occurred with Spain by issuing the 2006 Statute on expanding self-government for Catalonia, which stipulates that the Generalitat Catalonia has the authority to promote its interests abroad by respecting the competence of the center in international affairs, and the regional government can form its representative office abroad. This authority was later modified by the regional parliament so that Catalonia activity in other countries was not controlled by the Madrid government
(Yturriaga, 2019). In 2019, Catalonia had its diplomatic network in more than 39 countries on five continents and established its embassy in 15 countries, although, in 2017, Madrid had dissolved all of Catalonia's representatives abroad as many as 116 representatives (Government of Catalonia, 2019).

\section{CONCLUSION}

An examination of the arrangements and practices of paradiplomacy in Indonesia shows explicitly that Indonesia's policies/politics of paradiplomacy are in the conservative type in the typologies. Indicators show that the limitations of local government authority are rigorous. Meanwhile, the Korean Government gives regional governments the freedom to conduct foreign cooperation with foreign parties to promote trade, investment, agriculture, education, and others. Seen from this side, it can be categorized that Korea's policy diplomacy belongs to the progressive type.

The similarity regarding the issue of paradiplomacy between Korea and Indonesia is on the central government's role that still holds the general control on paradiplomatic activism in both countries, although the Korean Government gives more opportunities for the regional governments to manage paradiplomatic affairs technically.

The different domestic political conditions between Indonesia and Korea, related to the existence of secessionist movements that influence local politics, are a severe consideration to the Indonesian Government in designing its diplomacy policy in its regional autonomy framework. Meanwhile, the Korean Government do not face the issue of secessionism in its domestic politics. The relation between the center and the regions in the unitary state system has a different level of mutual trust in each country due to secessionism movements in some regions in certain countries. Indonesia is a sample of countries experiencing this case.

From the paradiplomacy policies implemented in Indonesia and Korea, the regional governments' responses to the central policy are also diverse, essential to be examined as an exploration and evaluation of policies beneficial for developing knowledge policymaking. 


\section{ACKNOWLEDGMENT}

The authors are grateful to Professor Bilveer Singh, Department of Political Science at the National University of Singapore, who shared essential facts about Papuan Political movements, and whose critical views enriched this article.

\section{REFERENCE}

ACPG, R. (2019). Africa Caribbean Pacific group seeks action on Papua rights abuses. Retrieved January 13, 2020, from RNZ: https://www.rnz.co.nz/international/pacific-news/405595/a frica-caribbean-pacific-group-seeks-action-on-pap ua-rights-abuses

Alami, A. N. (2016). Politik Luar Negeri Indonesia dan Isu Keamanan Non-Tradisional. Jurnal Penelitian Politik, 12(2), 87-103.

Aldecoa, F., \& Keating, M. (Eds.). (1999). Paradiplomacy in action: The foreign relations of subnational governments (Vol. 17). Taylor \& Francis US.

CBGMS. (2018). Chungbuk Global Marketing System. Retrieved December 30, 2019, from http://cbgms.chungbuk.go.kr/us/ index.jsp

Chan, D. K. (2016). City diplomacy and "glocal" governance: revitalizing cosmopolitan democracy. Innovation: The European Journal of Social Science Research, 29(2), 134-160.

Chng, B., Cook, A. D., \& Ewing, J. J. (2013). RSIS Non-Traditional Security (NTS): Year In Review 2013. Singapore: RSIS Center.

Choi, J., Choe, C., \& Kim, J. (2012). Local government and public administration in Korea. Retrieved December 30 2019, from K-Developedia: https://www.kdevelopedia.org/re source/view/04201603310144001.do\#.XhVLNEczY2w

CNN Indonesia. (2019, January 28). Diteken 1,8 Juta Orang, Petisi Referendum Papua Dibawa ke PBB. internasional. Retrieved December 2019, 2019, from CNN Indonesia: https://ww w.cnnindonesia.com/internasion al/20190128104032-134-364343/diteken-18-ju ta-orang-petisi-referendum-papua-dibawa-ke-pbb

Cornago, N. (2000, October). Exploring the global dimensions of paradiplomacy Functional and normative dynamics in the global spreading of subnational involvement in international affairs. Workshop on Constituent Units in International Affairs. Forum of Federations. Hanover.

Cornago, N. (2006). Paradiplomacy as international custom: sub-national government and the making of new global norms. Global Norms for the Twenty-First Century, 67(81), 67-81.

Cornago, N. (2010). On the normalization of sub-state diplomacy. The Hague Journal of Diplomacy, 5(1-2), 11-36.

Cornago, N. (2018). Paradiplomacy and Protodiplomacy. In G. Martel (Ed.), Encyclopedia of Diplomacy. Oxford: Blackwell-Wiley. doi:10.9781118885154.

Doherty, B. (2019). Indonesia anger as West Papua independence raised at Pacific forum. Retrieved January 13 2020, from The Guardian: https://www.theguardi an.com/world/2019/aug/12/indonesia-angered-as-west-pap ua-independence-raises-its-head-at-pacific-forum

FWPC. (2016). Free West Papua-Seven countries support West Papua at the UN General Assembly. Retrieved January 13, 2020, from Free West Papua Campaign: https://www.freew estpapua.org/2016/09/27/seven-countries-sup port-west-papua-at-the-un-general-assembly/

Government of Catalonia. (2019). Catalan government appoints representatives to Mexico, Argentina and Tunisia. Retrieved February 1, 2020, from Government of Catalonia: https:// catalangovernment.eu/catalangovernment/news/378025/ catalan-government-appoints-representatives-to-mexico-ar gentina-and-tunisia

Government of Gangwon. (2018). Expanding the Infrastructure for the Globalization of the Provincial Government. Retrieved January 13, 2020, from Government of Gangwon: http://eng.gwd.go.kr/gw/eng/sub02_05_02

Government of Gyeongbuk. (2015). International Trade. Retrieved January 11, 2020, from Government of Gyeongbuk: http://www.gb.go.kr/eng/page.jsp?largeCode=business\& mediumCode $=$ trade\&smallCode $=$ inter_trade\&LANG CODE $=$ English

Government of Gyeongbuk. (2016). International Relations. Retrieved January 13, 2020, from Government of Gyeong buk: http://www.gb.go.kr/eng/page.jsp?largeCode=busi ness\&mediumCode $=$ trade\&smallCode $=$ inter_rela tions\&LANGCODE $=$ English

Government of Seoul. (2019). City Diplomacy Vision. Retrieved February 1, 2020, from Seoul Metropolitan Government: http://english.seoul.go.kr/policy-information/internation al-exchange/city-diplomacy/city-diplomacy-vision/

Henschke, R. (2019, April 13). Where Chinese workers are causing controversy. Retrieved January 14, 2020, from BBC News: https://www.bbc.com/news/world-asia-47881858

Heo, I. (2018). The Paradox of Administrative Decentralization Reform in Young Asian Democracies: South Korea and Indonesia. World Affairs, 181(4), 372-402. doi:10.1177/0043820018813474

Hocking, B. (1986). Regional Governments and International Affairs: Foreign Policy Problem or Deviant Behaviour? International Journal, 41(3), 477-506. doi:10.1177/002070208604100301

KLRI. (2017). Local Autonomy Act. Retrieved January 11, 2020, from Korea Legislation Research Institute: https://elaw.kl ri.re.kr/eng_service/lawView.do?hseq $=44511$ \&lang $=$ ENG

KLRI. (2018). Statutes of the Republic of Korea. Retrieved February 1, 2020, from Korea Legislation Research Institute: https://elaw.klri.re.kr/eng_service/lawView.do?hse $\mathrm{q}=44511$ \&lang $=\mathrm{ENG}$

Korea.net. (2019). Local Government. Retrieved January 11, 2020 , from The official website of the Republic of Korea: http://w ww.korea.net/Government/Constitution-and-Govern ment/Local-Governments

Kuznetsov, A. S. (2014). Theory and practice of paradiplomacy: subnational governments in international affairs. Routledge.

Lecours, A. (2008). Political issues of paradiplomacy: lessons from the developed world. The Hague: Netherlands Institute of International Relations' Clingendael'.

Leffel, B. (2018). Animus of the Underling: Theorizing City 
Diplomacy in a World Society. The Haque Journal of Diplomacy, 13(4), 502-522. doi:10.1163/1871191X-13040025

Lequesne, C., \& Paquin, S. (2017). Federalism, Paradiplomacy and Foreign Policy: A Case of Mutual Neglect. International Negotiation, 22(2), 183-204. doi:10.1163/15718069-22001133

Li, M. (2019). China's Economic Power in Asia: The Belt and Road Initiative and the Local Guangxi Government's Role. Asian Perspective, 43(2), 273-295. doi:10.1353/apr.2019.0011

Liu, T., \& Song, Y. (2020). Chinese Paradiplomacy: A Theoretical Review. SAGE Open, 10(1). doi:10.1177/2158244019899048

LPS Initiative. (2015). Indonesia's Law No.23/2014 modifies Regional Autonomy Law. Retrieved February 1, 2020, from Decentralization \& Localization: http://www. decentraliza tion.net/2015/09/indonesia-law-23-2014/

Mahi, B. R. (2016). Indonesian Decentralization: Evaluation, Recent Movement and Future Perspective. Journal of Indonesian Economy and Business, 31(1), 119. doi:10.22146/ jieb.23567

Mukti, T. A. (2012). Sistem Pasca Westphalia, Interaksi Transnasional dan Paradiplomacy. Jurnal Hubungan Internasional, 2(2), 175-183 doi:10.18196/hi.2013.0039.175-183

Mukti, T. A. (2013). Paradiplomacy Kerjasama Luar Negeri oleh Pemda di Indonesia. The Phinisi Press Yogyakarta.

Mukti, T. A. (2019). Paradiplomacy and the Future of Aceh Government. 1st Aceh Global Conference (AGC 2018). Atlantis Press. doi:10.2991/agc-18.2019.8

Mukti, T. A., Warsito, T., Surwandono, Badruzaman, I., \& Pribadi, U. (2019). Paradiplomacy Management and Local Political Movement in Aceh, Indonesia, and Catalonia, Spain. European Journal of East Asian Studies, 18(1), 66-92. doi:10.1163/1570

Nasution, A. (2016). Government Decentralization Program in Indonesia. SSRN Electronic Journal. doi:10.2139/ss rn.2877579

NEAR. (2017). What is NEAR? Retrieved January 14, 2020, from The Association of North East Asia Regional Governments: http://www.neargov.org/en/page.jsp? mnu uid $=2597$

NGII. (2017). Local Autonomy and Decentralization. Retrieved February 1, 2020, from National Geographic Information Institute: http://nationalatlas.ngii.go.kr/pages/page 586.php

Nye, J. S., \& Keohane, R. O. (1971). Transnational relations and world politics: An introduction. International organization, 25(3), 329-349.

Papua Today. (2018). Gubernur Papua Hadiri PerayaaGubernur Papua Hadiri Perayaan Kemerdekaan PNG. Retrieved February 3, 2020, from Papua Today: https://www. papuato day.com/2018/09/16/gubernur-papua-hadiri-perayaan-ke merdekaan-png/

RNZ. (2019). West Papua solidarity march in PNG draws thousands. Retrieved February 3, 2020, from RNZ: https://W ww.rnz.co.nz/international/pacific-news/398511/west-pap ua-solidarity-march-in-png-draws-thousands

Rodrigues, G. M., \& Mattioli, T. (2017). Paradiplomacy, Security Policies and City Networks: The Case of the Mercocities Citizen Security Thematic Unit. Contexto Internacional,
39(3), 569-587. doi:10.1590/s0102-8529.2017390300006

Saputra, E. Y. (Ed.). (2019). OPM Menyatakan Perang terhadap Pemerintah RI. Retrieved December 29, 2019, from Tempo: https://dunia.tempo.co/read/1171296/opm-menyata kan-perang-terhadap-pemerintah-ri\#: : text =TEM PO.CO\%2C\%20Jakarta\%20\%2D\%20Organisasi,se lama\%20konpers\%20di\%20Papua\%20Nugini.

Singh, B. (2019). Why is West Papua in Constant Turmoil? Retrieved January 11, 2020, from The Diplomat: https://thediplomat.com/2019/09/why-is-west-papua-in -constant-turmoil/

Song, Y. (2019). Beyond the hinterland: exploring the international actorness of China's Yunnan Province. (Doctoral dissertation).

Surwandono, S., \& Ramadhani, M. A. (2016). Content Analysis of Indonesian National Security Architecture. International Conference on Ethics in Governance. doi:10.2991/icon eg-16.2017.34

Tavares, R. (2016). Paradiplomacy: Cities and states as global players. Oxford University Press.

Vicuňa, R. L. (2015). Catalan Paradiplomacy, Secessionism and State Sovereignty: The Effects of the 2006 Statute of Autonomy and the Artur Mas Government on Catalan Paradiplomacy. Leiden: Leiden University.

Wolff, S. (2007). Paradiplomacy: scope, opportunities and challenges. The Bologna Center Journal of International Affairs, 10(1), 141-150

Yturriaga, J. A. (2019). Catalan diplomacy catches up with you! Retrieved February 1, 2020, from The Diplomat: In Spain: https://thediplomatinspain.com/en/2019/07/catalan-diplo macy-catches-up-with-you/ 